\title{
DESIGN OF LEARNING MEDIA FOR AUDACITY-ASSISTED DOPPLER EFFECT PRACTICUM TOOLS
}

\author{
DESY WIDANINGRUM ${ }^{1}$, ROISQI KHOERIKA ${ }^{1}$, SUPRIYADI $^{2}$, SULHADI $^{2}$ \\ ${ }^{1}$ Postgraduate Physics Education Master Program, Universitas Negeri Semarang \\ ${ }^{2}$ Lecturer Staff, Department of Physics, Universitas Negeri Semarang, \\ Jl. Kelud Utara III Semarang 50237. Telp. 024-8440516 \\ *email : desywi23@students.unnes.ac.id
}

\begin{abstract}
The Doppler effect is one of the important materials in studying the sound of a still or moving object. The purpose of this study is to develop learning media in the form of Doppler effect practicum tools assisted with audacity. The research method used is Research and Development (R \& D). The product produced in this study is a Doppler Effect practicum tool in the form of a source car and a listener car equipped with a speed controller as a speed controller and a speaker as a sound source, a trajectory as long as 3 meter, as well as assisting with audacity on a personal computer or laptop. The audacityassisted hearing frequency measurement tool was tested by varying the speed of the source car and the direction of the source car, the approaching and farther away from the listener's car. The results of the measuremen of this tools are in accordance with theoretical calculations, having a difference of $0.81 \mathrm{~Hz}$ at a speed of $0.33 \mathrm{~m} / \mathrm{s}$, a difference of 3.05 at a speed of $0.38 \mathrm{~m} / \mathrm{s}$, and a difference of 3.88 at a speed of $0.44 \mathrm{~m} / \mathrm{s}$. The relative accuracy of the measurement results to the comparative theoretical value by calculation is $99.9 \%$. Based on the results of this study, it can be concluded that the learning media in the form of Doppler effect practicum tools assisted by audacity that were designed can be applied in physics learning.
\end{abstract}

Keywords: audacity, Doppler effect, practicum tools

\section{Introduction}

Learning is not only the process of memorizing and stacking up science, but how the knowledge gained by students is meaningful through thinking skills, so that when the teacher teaches with lectures, then the student will remember and master the lesson only $20 \%$, because the student only listens. Conversely, if the teacher asks him to do something and report it, then the student will remember it and finish the lesson $90 \%$.

In accordance with the curriculum syllabus 2013 in KI 4, namely processing, reasoning, and presents in the realm of concrete and abstract realms related to the development of what he learned in school independently, and able to use methods according to scientific rules, then in learning physics in school is very necessary the existence of practicum activities as a form of learning from processing, reasoning and presents activities.

Based on observations in science laboratories at Smp and SMA Al Fusha Kedungwuni Pekalongan Regency, there are several physical practicum tools including hydrostatic kits, lens and mirror optical kits, and kinematic kits. These tools have not been maximally used due to time constraints and skills using inadequate tools. In addition, there is no practicum tool for sound wave material. 
The material about the sound waves themselves is diverse, one of which is the sub chapter of the doppler effect. The doppler effect is the material given in grade XI high school in the second semester. The concept of abstract sound waves often makes it difficult for students to understand if only imagined. Therefore, a physics measuring tool on the doppler effect phenomenon needs to be developed to make it easier for students to understand the influence of each magnitude on the phenomenon of doppler effect as a practicum medium in schools.

\section{Methods}

The study method used was an experiment by developing an audacity-assisted doppler effect practicum tool. In the development of this practicum tool, the comparison of listener frequency measurement results using audacity with the results of theoretical calculations in accordance with the concept of doppler effect, namely.

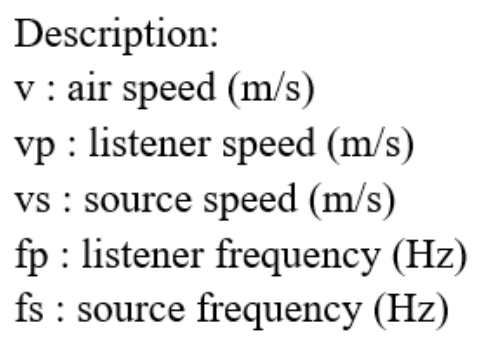

$$
f_{p}=\left(\frac{v \pm v_{p}}{v \pm v_{s}}\right) f_{s}
$$

The measurement of the frequency of both the source and the frequency received by the listener is done with audacity. Audacity is an open source sound effecter built with the WxWidgets library. The system is stable, can be used as a sound recording tool, manipulate audio files, and change the type of audio files. So that from this sound recording can be detected the frequency of sound every second. The design of practicum tools developed is as follows.

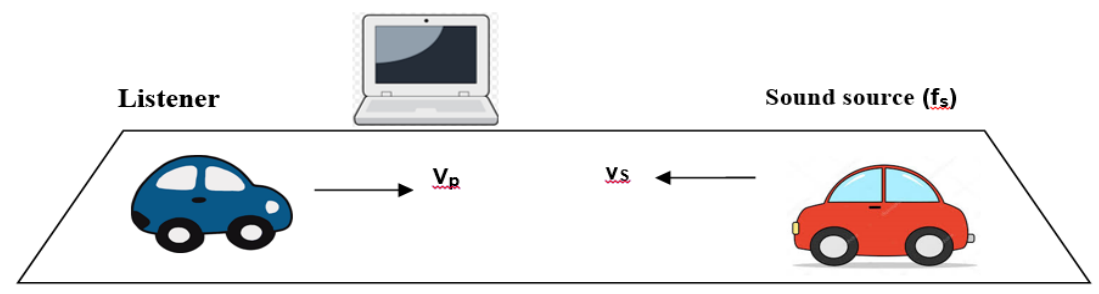

Figure 1. Doppler Effect Practicum Tool Design

\section{Results and Discussion}

\subsection{Characteristics of Doppler Effect Practicum Tools}

The process of making practicum tools, it is produced a learning media doppler effect practicum tool assisted audacity in accordance with the concept of doppler effect. The resulting practicum tools help students to become more understanding and appreciative in the learning process, as Conveyed by Wieman in Hapsoro et al.(2009). 
This study have been compiled on a discussion on the development of learning media in the form of doppler effect practicum tools assisted audacity as a support for doppler effect material at the high school level. The practicum tool consists of a sound source car equipped with a speed controler as a speed regulator, as well as speakers as sound output. Next, the listening car, the track to make the car run straight, and help audacity to measure the frequency of sound coming out of the speakers. Here are the results of the development of the audacity-assisted doppler effect practicum tool, show on the Figure 2 (a) and Figure 2 (b).
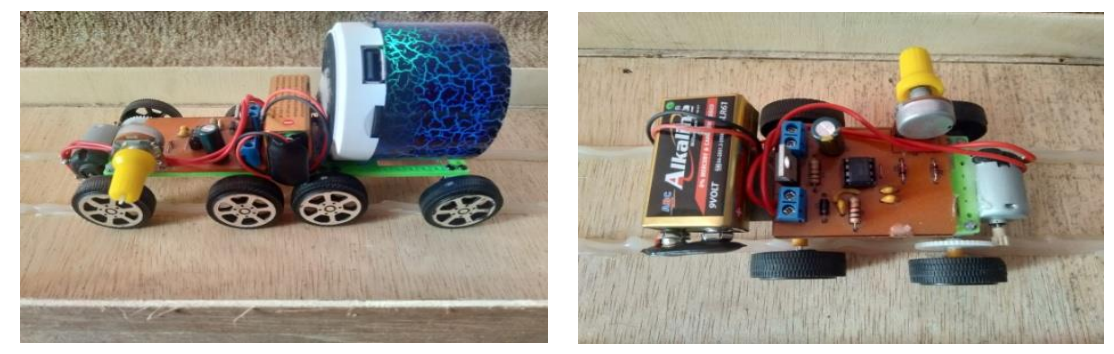

Figure 2. (a) source car (b) source listener

\subsection{Frequency Measurement}

Learning Media doppler effect practicum tools have been tested. Used 3 variations of source speed in the practicum of the doppler effect, namely $0.33 \mathrm{~m} / \mathrm{s} ; 0.38 \mathrm{~m} / \mathrm{s}$; and $0.44 \mathrm{~m} / \mathrm{s}$, while the silent listener speed is $0 \mathrm{~m} / \mathrm{s}$. The air speed used at normal temperatures is $343 \mathrm{~m} / \mathrm{s}$. The frequency of siren source is measured by audacity with frequency value reading using plot analysis of pik/peak sound frequency spectrum. The frequency obtained from the audacity measurement is $983 \mathrm{~Hz}$. The audacity box dialog is shown by Figure 3.

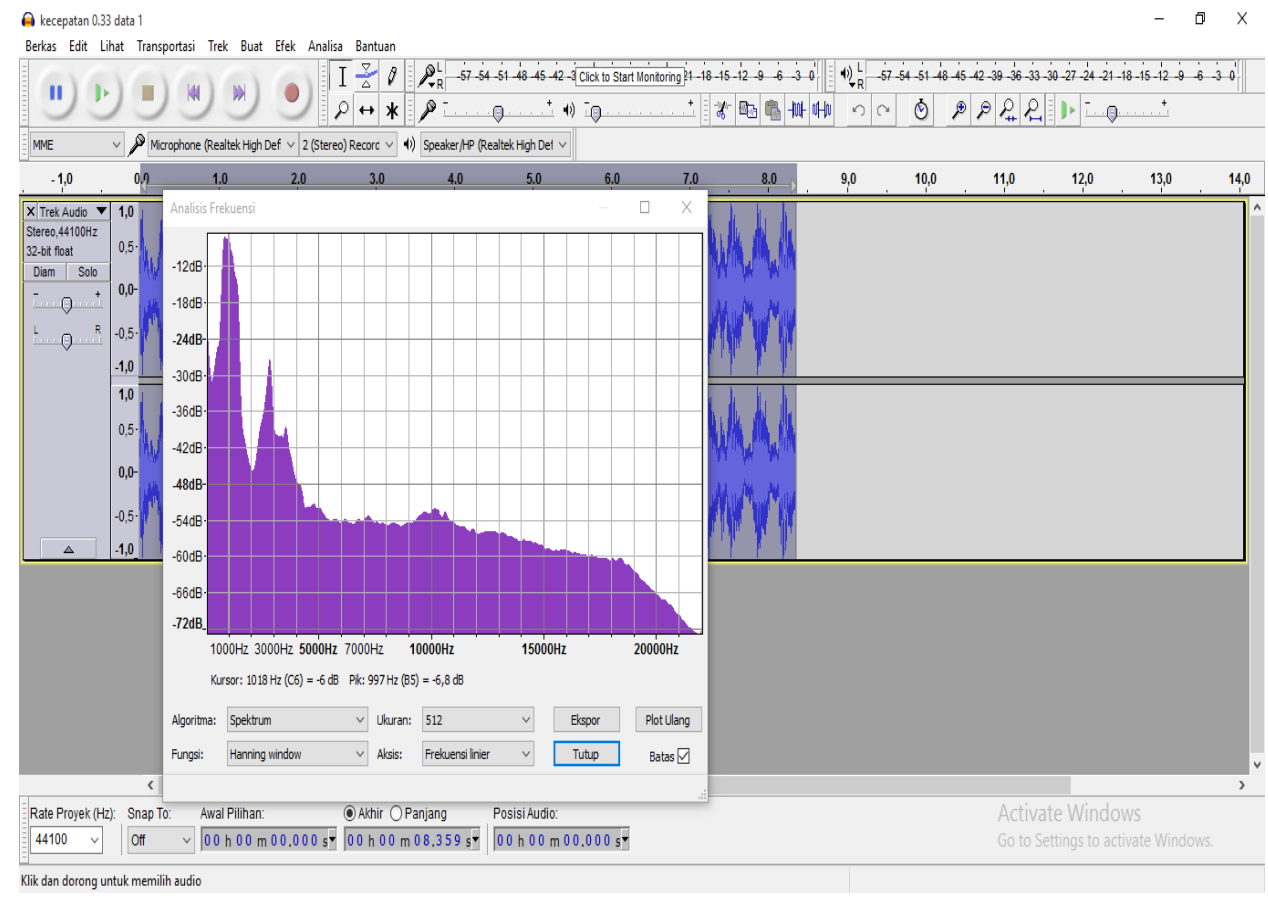

Figure 3. Doppler Effect Practicum Tool Design 
Speed variation is obtained through calculations with the concept of regular straight motion, namely by measuring the distance traveled and the time used by the car in a certain distance, so that the speed of the car is obtained. Variations in car speed can be done using a series of speed controllers on the car, while the source frequency and frequency of listeners are obtained from graph analysis on audacity. Audacity is operated with a personal computer or laptop placed near the car.

In practicum doppler effect was conducted tool trial with 3 variations of source speed. Audacity measured listener frequency based on 7 data obtained resulted in the average listener frequency in Table 1. Following.

Tabel 1. Doppler Effect Practicum Results

\begin{tabular}{ccccc}
\hline $\begin{array}{c}\text { Variatio } \\
\mathbf{n}\end{array}$ & $\begin{array}{c}\text { Source Speed } \\
(\mathbf{m} / \mathbf{s})\end{array}$ & $\begin{array}{c}\text { Listener Speed } \\
(\mathbf{m} / \mathbf{s})\end{array}$ & $\begin{array}{c}\text { Frequency } \\
\text { Source }(\mathbf{H z})\end{array}$ & $\begin{array}{c}\text { Listener } \\
\text { Frequency }(\mathbf{H z})\end{array}$ \\
\hline 1 & 0,33 & 0 & 983 & 983,14 \\
\hline 2 & 0,38 & 0 & 983 & 987,14 \\
\hline 3 & 0,44 & 0 & 983 & 988,14 \\
\hline
\end{tabular}

Furthermore, the calculation of listener frequency in accordance with the concept of doppler effect, namely on the state of the source car approaching the listener car, obtained the results of the calculation in Table 2 as follows.

Tabel 2. Comparison of Practicum Results \& Theory Frequency of Practicum Listeners (Hz)

\begin{tabular}{ccccc}
\hline Var & $\begin{array}{c}\text { Speed } \\
\text { Source } \\
(\mathbf{m} / \mathbf{s})\end{array}$ & $\begin{array}{c}\text { Frequency of } \\
\text { Practicum Listeners } \\
\mathbf{( H z )}\end{array}$ & $\begin{array}{c}\text { Theory Listener } \\
\text { Frequency } \mathbf{( H z )}\end{array}$ & $\begin{array}{c}\text { Relative } \\
\text { Accuracy }\end{array}$ \\
\hline 1 & 0,33 & 983,14 & 983,95 & $99,9991 \%$ \\
\hline 2 & 0,38 & 987,14 & 984,09 & $99,9969 \%$ \\
\hline 3 & 0,44 & 988,14 & 984,26 & $99,9960 \%$ \\
\hline
\end{tabular}

Based on Table 2. It is seen the frequency of listeners obtained in the measurement of practicum doppler effect in accordance with the calculation of theory with the concept of doppler effect. The difference in variation data 1 of 0.81 is greater in theory calculation, variation 2 data has a difference of 3.05 greater in practicum measurement, while data variation 3 has a difference of 3.88 greater in practicum measurement. Looking at the differences obtained is not too far away, shows the practicum tool of this doppler effect works well, according to the calculation of the theory.

Furthermore, experiments were also carried out when the source car moved closer or away from the listening car with variations in the distance of both cars. The following is presented in Table 3.

Based on Table 3 it appears that when the distance changes then the frequency captured by the listener changes, the greater the separation distance of the two cars, the smaller the frequency value received by the listener, and conversely the smaller the distance between the two cars, the greater the frequency captured by the listener. The relationship of distance with the frequency of listeners is applicable to the 
source car that is closer to the listener or away from the listener, so that from the data is seen the suitability of the results of practicum tool experiments with the concept of doppler effects.

Tabel 3. Listener Frequency with Variations in Distance and Direction of Motion

\begin{tabular}{ccc}
\hline $\begin{array}{c}\text { Second } \\
\text { Distance } \\
\text { Car }(\mathbf{m})\end{array}$ & $\begin{array}{c}\text { Listener Frequency } \\
\text { Approaching Each Other } \\
(\mathbf{H z})\end{array}$ & $\begin{array}{c}\text { Listener Frequency } \\
\text { Away from Each Other } \\
(\mathbf{H z})\end{array}$ \\
\hline 0,15 & 1065 & 996 \\
\hline 0,34 & 1013 & 970 \\
\hline 0,36 & 996 & 945 \\
\hline 0,98 & 970 & 940 \\
\hline 1,63 & 966 & 928 \\
\hline 2,34 & 938 & 921 \\
\hline
\end{tabular}

The results of study on the development of learning media doppler effect practicum tool shows the existence of practicum data and calculations of theories that are synchronous and corresponding. This shows that practicum tools can be used to support the learning process.

\section{Conclusions}

Overall the doppler Effect Physics material practicum system went well with results that fit the concept of theory and helped in the learning of physics concepts. This set of tools is able to display the results of sound frequency measurement in practicum practicum Doppler Effect with valid results with $99.9 \%$ accuracy. This study still has shortcomings where practicum is done with road route media for cars there is friction so as to cause additional sounds as a nuisance that becomes additional input frequency of sound that allows to cause the value of sound frequency is not purely from the source of sound.

\section{References}

1. S. R. Hidayat, "Pengembangan Instrumen Tes Keterampilan Pemecahan Masalah pada Materi Getaran, Gelombang, dan Bunyi”, JPPPF (2017), vol. 3, no. 2, pp. 157 -166, Dec. 2017.

2. M. C. Haisy, I. M. Astra, and E. Handoko, "Pengembangan alat peraga resonansi dan efek doppler berbasis soundcard pc/laptop untuk meningkatkan motivasi belajar fisika siswa sma", prosiding SNF (2015), vol. 4, pp. SNF2015II, Oct. 2015.

3. Habibi N., \& Imam S., "Perancangan Alat Ukur Kecepatan Menggunakan Sensor Ultrasonik Dan Prinsip Efek Doppler", Jurnal Inovasi Fisika Indonesia, (2015), vol. 4, No 3,48-54.

4. Arifin Fatihul, dkk. "Pengembangan Alat Praktikum Pelayangan Bunyi Dan Efek Doppler Berbasis Modul Mikrofon Kondenser Dan Mikrokontroler". Prosiding SNF, vol. 8, pp. 03.SNF2019. Dec.2019.

5. Karimah H.N, dkk. "Pengembangan Alat Peraga Efek Doppler". Prosiding Seminar Nasional The $5^{\text {th }}$ Lontar Physics Forum (2019). 
6. Sugiyono. Metode Penelitian Pendidikan Pendekatan Kuantitatif, Kualitatif Dan R\&D Bandung:Alfabeta. (2012). 